Bangladesh J. Zool. 39(2): 223-230, 2011

\title{
PREVALENCE AND SEASONAL VARIATION OF ECTOPARASITE IN PIGEON, COLUMBA LIVIA (GMELIN, 1789) OF DHAKA, BANGLADESH
}

\author{
Aleya Begum* and Sabrina Sehrin \\ Department of Zoology, University of Dhaka, Dhaka-1000, Bangladesh
}

\begin{abstract}
A total of 60 pigeons, Columba livia (25 males and 35 females) were examined for ectoparasites. All the birds were infected $(100 \%)$ by 10 species of ectoparasites. The ectoparasite comprised lice: 60 (100\%) Menopon gallinae, 28 (46.66\%) Menacanthus stramineus, 43 (71.66\%) Colpocephalum turbinatum, 60 (100\%) Columbicola columbae, 31 (51.66\%) Lipeurus caponis, 19 (31.66\%) Goniocotes gallinae, 28 (46.66\%) Chelopistes meleagridis; fleas: five (8.33\%) Echidnophaga gallinacean; flies: 38 (63.33\%) Pseudolynchia canariensis and eight (13.33\%) of mites Dermanyssus gallinae. Serious damage was observed in wing feathers $(31.74 \%)$. The females had a higher intensity (30.11) of infestation than the males (29.04). The ectoparasites were removed from the pigeons throughout the year. The overall intensity of infestation was highest during summer (40.69) and lowest during winter (21.94).

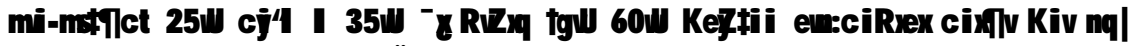

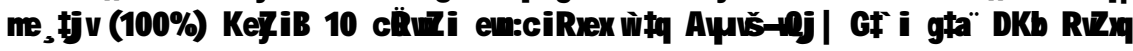
ciR xex, fj u msL "vI kZKi vms gb nfj v. $60(100 \%)$ Menopon gallinae, 28 (46.66\%) Menacanthus stramineus, $43(71.66 \%)$ Colpocephalum turbinatum, $60 \quad(100 \%)$ Columbicola columbae, 31 (51.66\%) Lipeurus caponis, 19 (31.66\%) Goniocotes gallinae, 28 (46.66\%) Chelopistes meleagridis; GKW w $\neg R$ V X X ci R xex 5 (8.33\%) Echidnophaga gallinacean; GKW gWQ R VZ $\times 38$ (63.33\%) Pseudolynchia canariensis Ges GKW gBU R R Xq ciRxex 8 (13.33\%) Dermanyssus gallinae. c KL u cj 抽 g gła"

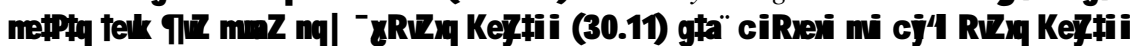

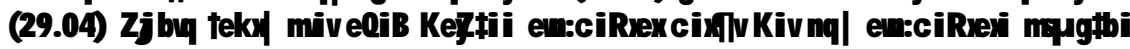
nu Mäß)

Key words: Ectoparasites, pigeon, prevalence, intensity, season.
\end{abstract}

\section{INTRODUCTION}

The pigeon (Columba livia) is kept as pet and reared for food in several countries including Bangladesh, it's interaction with man and other domestic and wild birds, portends it as a potential carrier of zoonotic parasites.

Ectoparasites are regarded as the basic causes of retardation in growth, lowered vitality and poor conditions of the birds (Ruff 1999). They can affect bird health directly by causing irritation, discomfort, tissue damage, blood loss, toxicosis, allergies and dermatitis which in turn reduce the quality and quantity of meat and egg production.

*Corresponding author. E-mail: aleya2000@hotmail.com 
It has been reported that ectoparasites affect the health and productivity of birds, initiate excessive preening which interrupts feeding, as the birds spend much time preening rather than being involved in other essential life activities (De Vaney 1979, Clayton et al. 1999).

The prevalence and intensity of parasitic infestations may be influenced by a number of epidemiological factors including host factors (age, sex and breed) and environmental factors (climatic conditions) (Nadeem et al. 2007).

\section{OBJECTIVES}

The present investigation was concentrated on the occurrence of ectoparasite infestation in different organs, sex and seasons of pigeon. The infection status was also recorded.

\section{MATERIAL AND METHODS}

Sampling area: The sampling was carried out in different areas of Dhaka city. The host was collected on monthly basis at regular intervals.

Sampling size and technique: A total of 60 pigeons (25 males and 35 females) were randomly selected from the area under study over one year period from February 2010 to January 2011.

Parasitological examinations: Ectoparasites were collected from live hosts by placing them in a large jar with a special lid that permitted the head of the bird to protrude. A filter paper dipped in chloroform was placed at the bottom of the jar. The bird was restrained with its body in the jar for about 20 minutes. During this time many dying parasites detached and fell off. The bird was then removed and placed on a piece of white paper.

Different regions of the bird's body was examined for parasites. Care was taken to avoid the intermixing of parasites of one region of the body with those of the other regions. In the birds suspected for infestation with mites, deep scrapings were done by using a scalpel or knife blade and their sites noted.

The ectoparasites were counted and preserved in labeled vials containing $70 \%$ alcohol and a drop of glycerin (Soulsby 1982 and Loomis 1984). All types of ectoparasites thus collected were categorized. Permanent preparations were made and then the slides were identified on the basis of their morphological characters following Fabiyi (1980) and Soulsby (1982).

Data analysis: Prevalence of individual parasite species was calculated as a percentage of the host population that was infested with a specific parasite at a point in time (Thrusfield 1995). Intensity was calculated as the number of parasites per infected birds. Chi squire analysis was used to compare the 
intensity of parasite infestation between male and female pigeons using the SPSS ${ }^{\circledR}$ computer software.

\section{RESULTS AND DISCUSSION}

Of the 60 pigeons examined, all the birds were infested (100\%) with ectoparasites. Ten species of ectoparasites were identified, which comprised seven species of lice, viz. Menopon gallinae (100\%), Menacanthus stramineus (46.66\%), Colpocephalum turbinatum (71.66\%), Columbicola columbae (100\%), Lipeurus caponis (51.66\%), Goniocotes gallinae (31.66\%), Chelopistes meleagridis (46.66\%); one species of fleas Echidnophaga gallinacean (8.33\%); one species of flies Pseudolynchia canariensis (63.33\%) and one species of mites Dermanyssus gallinae (13.33\%) (Table 1).

Table 1. Prevalence and intensity of arthropod infections in C. livia.

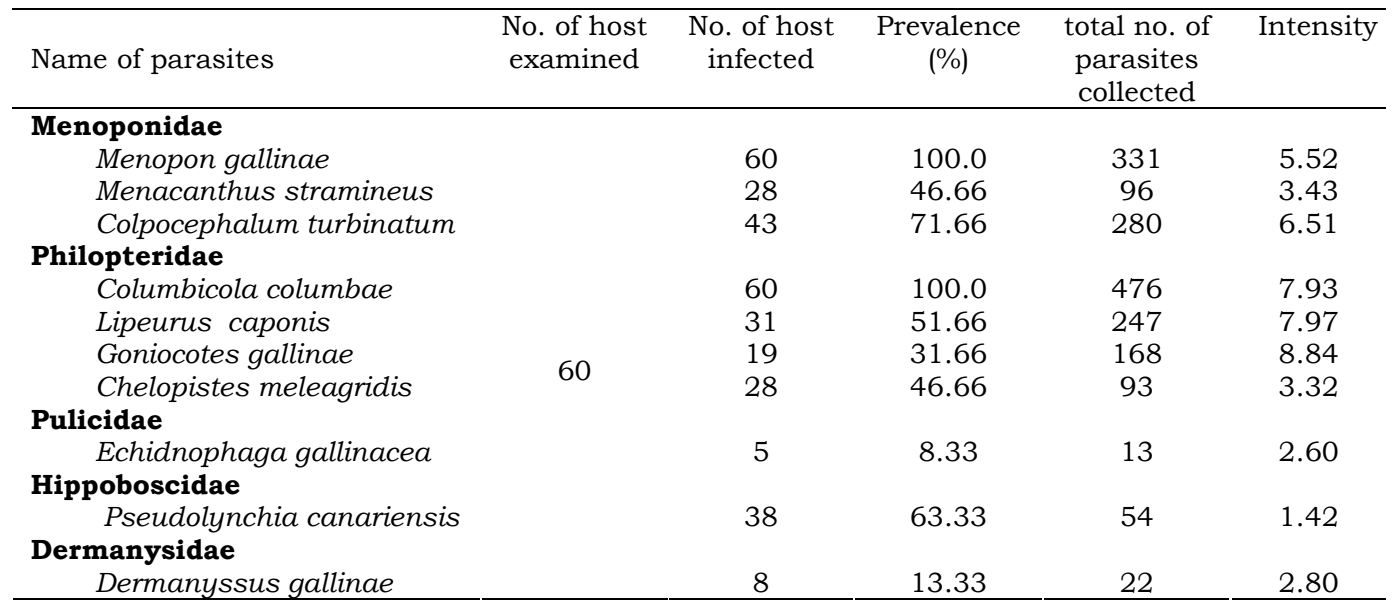

The ectoparasites were removed from different sites on the body of the birds: M. gallinae, M. stramineus, C. turbinatum, G. gallinae and C. meleagridis from down and contour feathers of skin, trunk, rump and nape feathers, C. columbae and L. caponis from quill feathers of wing and tail, E. gallinacean from down and contour feathers of skin and limb, $P$. canariensis from down and contour feathers of skin, trunk, rump and nape feathers, and quill feathers of wing, and D. gallinae from down and contour feathers of skin, trunk and limb (Table 2).

Out of 60 pigeons, 35 were females and 25 were males. The overall prevalence of infestation was $100 \%$ in both sexes and the intensity of females was higher (30.11) than the males (29.04). The male and female birds had 10 ectoparasite species each and the Chi square test revealed insignificant difference $(p>0.05)$ in the intensity of infestation between male and female birds. 
M. gallinae and C. columbae showed $100 \%$ prevalence both in male and female birds. Highest (10.88) intensity was found in L. caponis in male and 8.45 was $G$. gallinae in female pigeon. Both male and female hosts' lowest prevalence and intensity was observed in E. gallinacean and P. canariensis (Table 3).

Seasonal pattern of parasite prevalence and mean intensity of infestation are given in Table 4. Menopon gallinae and C. columbae were the most prevalent ectoparasites. They were found throughout the year and the prevalence was $100 \%$ in Summer. Echidnophaga gallinacean showed the lowest prevalence, it was absent in Autumn and Winter but in Summer the prevalence was $23.08 \%$ and in Spring it was $12.50 \%$. The other prevalent ectoparasites were $L$. caponis and C. meleagridis $92.31 \%$ in Summer and P. canariensis showed $92.86 \%$ prevalence in Autumn.

No studies has been done on the ectoparasites of pigeon in Bangladesh. This study thus provides a baseline or preliminary information on the subject. In the present study lice, fleas, flies and mites were observed. Almost all the birds were found to be infested with different types of ectoparasites throughout the year and each bird was found to harbour more than one type of ectoparasites.

The overall prevalence $(100 \%)$ of ectoparasites on pigeons in Bangladesh appears to be high compared to 73.8 and $72 \%$ found in pigeons by Adang et al. (2008) and Senlik et al. (2005), respectively. Ten ectoparasite species were collected from pigeons compared to nine by Conti and Forrester (1981), five by Adang et al. (2008) and three by Senlik et al. (2005). The overall prevalence of various parasites differs greatly among the previous reports as well as when compared with present observation. Diversity of bird ectoparasite assemblages may be related many factors, which may include home range, behaviour, size and roosting habit of the host. This may also be attributed to difference in the geographical areas and period of study.

Parasites living mainly on the skin may cause the affected birds to be restless, unable to sleep, suffering from overall weakness, reduced food intake with a consequential loss of weight, resulting in decreased resistance to pathogens, as well as their potential ability to reproduce (Wall and Shearer 2001, Mullen and Durden 2002). In particular, heavy infestations with $C$. turbinatum may cause severe damage to the flight feathers. Lice can perforate the large wing and tail feathers. These perforations increase during heavy infestations, with considerable loss of areas of the wing surface and lower flight efficiency (Selim et al. 1968). In heavy infestations, lice can also be observed inside the feather quills (Naz et al. 2010, Fasungova et al. 2008). 


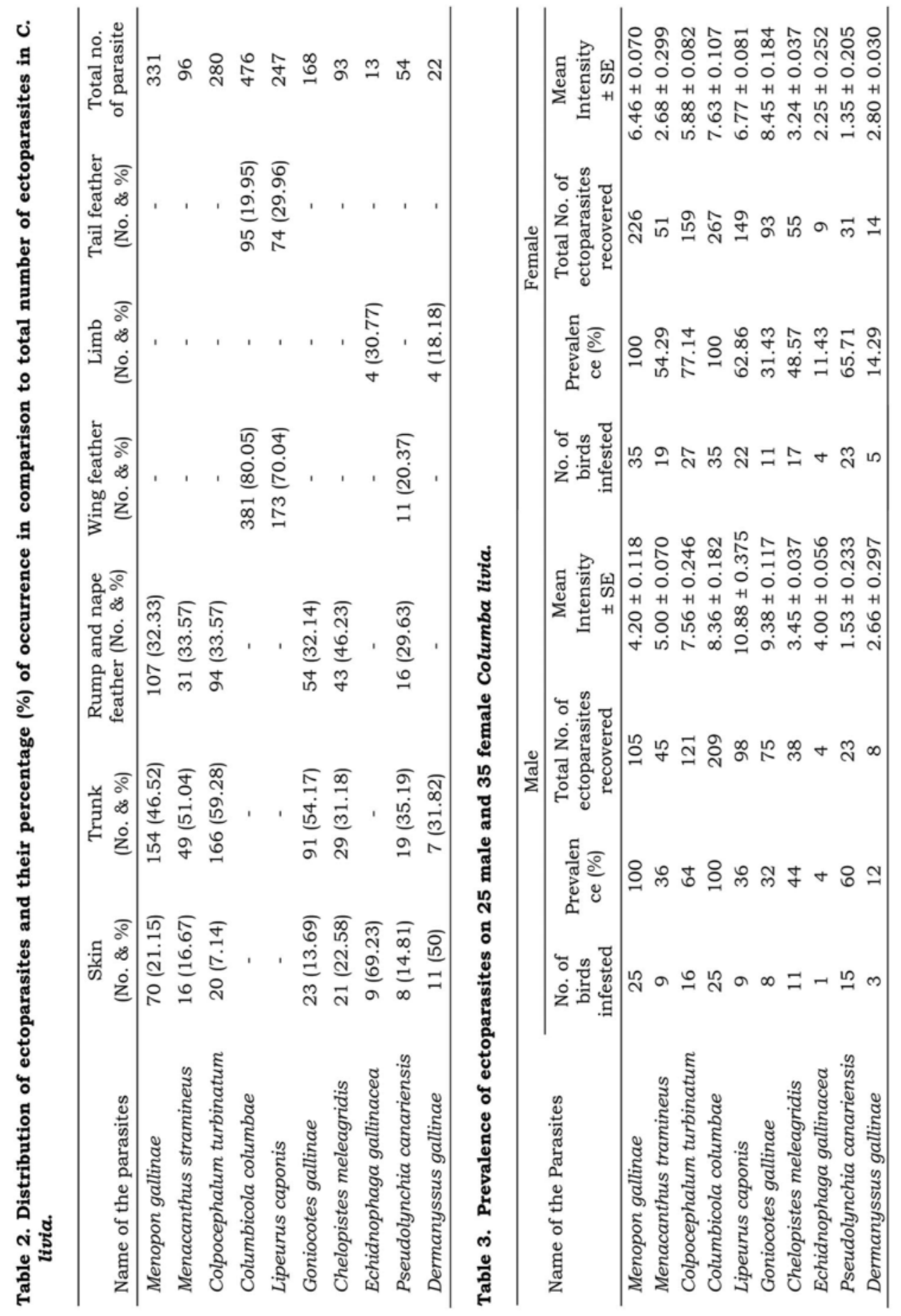




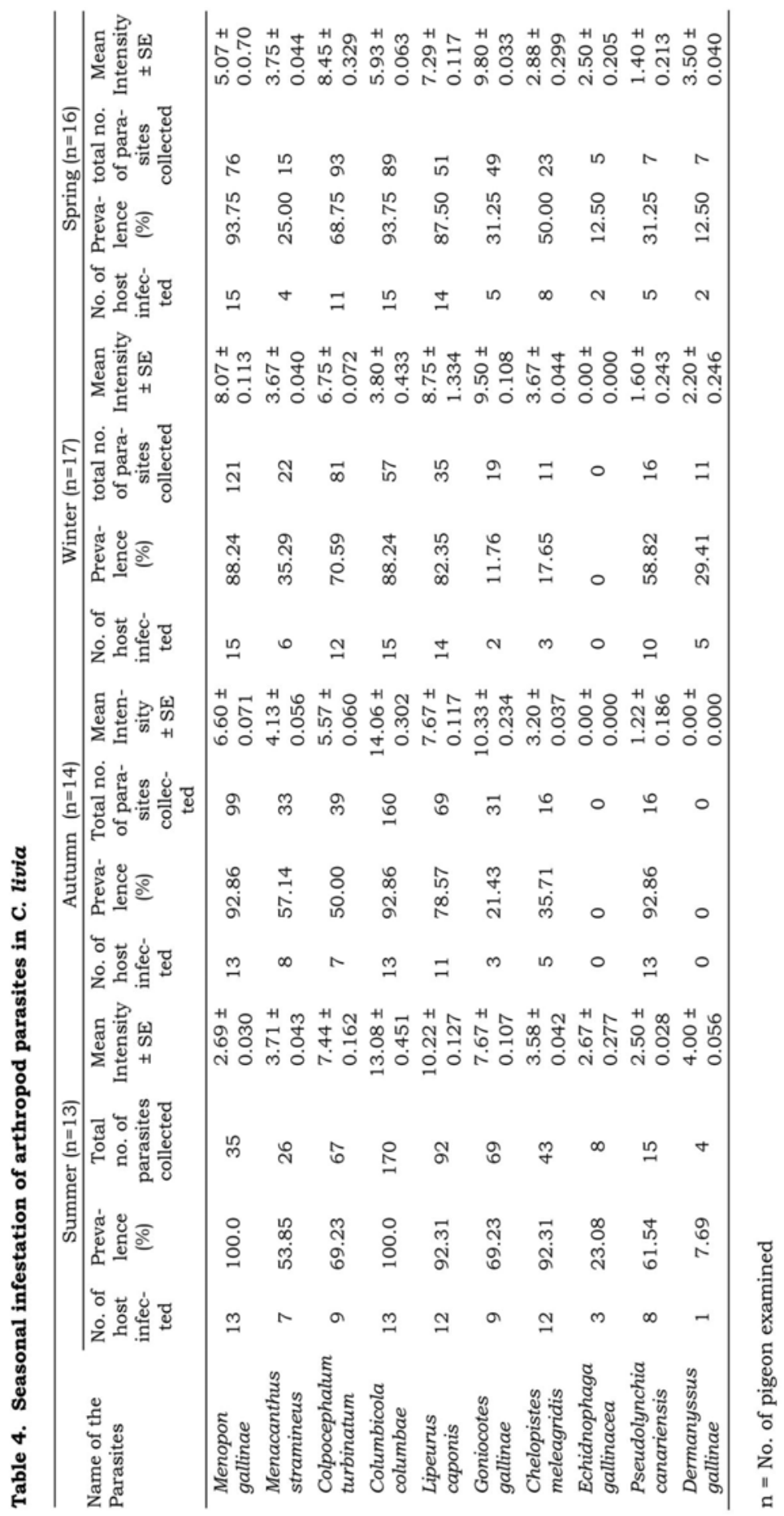


The non-statistically significant association between sex and ectoparasite infestation indicates that both males and females are equally exposed to the acquisition of ectoparasites and their sex related physiognomy may not confer any differences in infestation. This result is in agreement with the observations of Adang et al. (2008) and Senlik et al. (2005), who reported no significant difference between male and female pigeons in overall ectoparasite infestation.

In general, prevalence was highest during summer and lowest during winter. Also the parasitic load was higher during summer for M. gallinae, C. columbae, L. caponis, and C. meleagridis. During autumn Pseudolynchia canariensis showed higher prevalence. The observations could be related to the higher temperature and humidity during these months. Adang et al. (2008) also reported C. columbae and $P$. canariensis were the most prevalent ectoparasite of domestic pigeon in summer. Salam et al. (2009) observed L. caponis was the most prevalent among ectoparasites in free-range chicken of Kashmir valley. The prevalence and intensity of infestation were positively correlated to temperature, both being followed by autumn and least in winter (Nadeem et al. 2007). The increased prevalence of ectoparasites during summer months can be attributed to the requirement of optimum temperatures for the development of parasites and decreased resistance of birds to the parasites in high temperatures resulting in heavy infections.

\section{CONCLUSION}

The present study shows that pigeons have high prevalence of ectoparasite infestation. Parasitic infestation in almost all cases are harmful to their host. Columba livia is infected by arthropod mallophagan ectoparasites when they live in non-hygienic conditions. The ectoparasites are feather eaters and cling to the feather by means of their tarsal curved claws.

\section{LETERATURE CITED}

ADANG, K.L., ONIYE, S.J., EZEALOR, A.U., ABDU, P.A., and AJANUSI, O.J. 2008. Ectoparasites of domestic pigeon (Columba livia domestica, Linnaeus) in Zaria, Nigeria. Res. J. Parasitol. 32: 984.

CLAYTON, D.H., LEE, P.L.M., TOMPKINS, D.M., and BRODIE, E.D. 1999. Reciprocal natural selection on host-parasite phenotypes. Amer. Naturalis 1547: 261-270.

CONTI, J.A. and FORRESTER, D.J. 1981. Inter relationship of parasites of white-winged dove and mounting doves in Florida. J. Wildlife Dis. 174: 529-536.

DE VANCY, J.A., 1979. The effects of the Northern fowl mite, Ornithonyssus sylviarum on egg production and body weight of caged White leghorn hens. Poultry Science 575: 191-194.

FABIYI, J.P. 1980. Survey of lice infesting domestic fowl on the Jos Plateau, Northern Nigeria. Bull. Animal Health and Product. 283: 215-219. 
FASUNGOVA, K.C., LITERÁK, I., SYCHRA, O., NOVOTNÝ, L., GRYMOVÁ V., KUBÍČEK, O., SMÍD B. and KULICH, P. 2008. Pinching off syndrome in two White-Tailed Sea Eagles (Haliaeetus albicilla) in the Czech Republic. J. Raptor Res. 42: 65-66.

LOOMIS, E.C. 1984. External Parasites, In: Diseases of Poultry, Hotstad, M.S., B.W. Calnek and H. W. Jr. Yoder (Eds.). $8^{\text {th }}$ Edn. The lowa State University Press, pp. 667-704.

MULlEN, G.R. and DURDEN, L.A. 2002. Medical and Veterinary Entomology. Academin Press: London, pp. 597.

NADEEM, M., KHAN, M.N., IQBAL, Z., SAJID, M.S., ARSHAD, M. and YASEEN, M. 2007. Determinants influencing prevalence of louse infestations on layers of district Faisalabad (Pakistan). Brit. Poul. Sci. 485: 546-550.

NAZ, S., RIZVI, S.A. and SYCHRA, O. 2010. The high rate of infestation of chewing lice (Phthiraptera) in rock pigeon (Columba livia Gmelin 1789) in Pakistan. Trop. Zool. 23: 21-28.

RUFF, M.D. 1999. Important parasites in poultry production systems. Veterinary Parasitol. 843-4: 337-47.

SALAM, S.T., MIR, M.S., and KHAN, A.R. 2009. Prevalence and seasonal variation of ectoparasite load in free-range chicken of Kashmir valley. Trop. Animal Health Product. 41: 1371-1376.

SELIM, M.K., EL-KASABY, A. and EL-REFALL, A.H. 1968. External parasites of domestic pigeon in United Arabic Republic. Angewandte für Parasitologie 9: 74-84.

SENLIK, B., GULEGEN, E. and AKYOL, V. 2005. Ectoparasites of domestic pigeon (C. l. domestica) in Bursa Province. Türkiye Parazitoloji Dergisi. 292: 100-102.

SOULSBY, E.J.L.1982. Helminths, Arthropods and Protozoa of Domesticated animals. $7^{\text {th }}$ edn. (Bailliere Tindall, London), pp. 809.

THRUSFIELD, M. 1995. Veterinary epidemiology, $2^{\text {nd }}$ edn, (Black-well Scientific, Oxford).

WALL, R., and SHEARER, D. 2001. Veterinary ectoparasites: Biology, pathology and control, $2^{\text {nd }}$ edn. Lnodon: Wiley Blackwell, pp. 304.

(Manuscript received on December 20, 2011; revised on February 7, 2012) 